\title{
A study case of Baranca drainage basin flash-floods using the hydrological model of Hec-Ras
}

\author{
Aritina HALIUC $^{1^{*}}$ and Alexandru FRANTIUC ${ }^{2}$ \\ 1 Stefan cel Mare University, Suceava, Romania \\ 2 Brandenburg University of Technology, Cottbus, Germany \\ * Correspondence to: Aritina Haliuc, Stefan cel Mare University, Suceava, Romania. E-mail: aritinahaliuc@gmail.com \\ (C2012 University of Suceava and GeoConcept. All rights reserved \\ doi: 10.4316/GEOREVIEW.2012.21.1.61
}

\section{Article history}

Received: August 2012

Received in revised form:

October 2012

Accepted: November 2012

Available online: Jan. 2013

\begin{abstract}
In the last decades, the floods which occurred within Romanian territory stand as proof for the increased frequency of the extreme hydrological hazards which have negative effects on the normal pathway of the human-beings activities. The technological progress among with the increased frequency of floods events are the base for the development of informational programs for the analysis, simulation and flood management. The Baranca brook which drains a considerable part of Zamostea village (Romania) was used as a pilot drainage basin for the flash-flood simulation using the Hec-Ras program and the Arcgis extension, HecGeo-Ras. The flash-floods that occurred in the summer of 2010 were used to validate the results of the simulation. Between 28.06.2010 - 29.06.2010, two flash-floods occurred in the Baranca drainage basin with a discharge oscillated between $10 \mathrm{~m}^{3}$ and $70 \mathrm{~m}^{3}$, a water extent which covered an area of $5.14 \mathrm{~km}^{2}$ and a depth ranging between $0.3-3 \mathrm{~m}$. The programs are capable to simulate the water flow and to investigate the floodway encroachments in the study area. The damages evaluated in the field along with the program's results reveal the fact that more than half of the built-up areas of Zamostea village are established along brooks, within the floodplain area. What is more, after the 2010 floods, the expension of the habitable area was not detained by the water danger, many houses are still built on the floodplain. The programs used, taking an acceptable margin of error, may be integrated into any flood management strategy or in any watershed plan and may provide the necessary support for mitigating the risks associated with floods.
\end{abstract}

KEY WORDS: Hec-Ras, HecGeo-Ras, flash-floods simulation

\section{Introduction}

The increase of floods frequency has inflicted important losses on the socio-economic environment and thereby, it would be necessary the development of flood management through the understanding of the floods phenomenon. Even though, the flood is part of humans being 
life, it cannot be totally controlled. Moreover, it would be necessary to focus on the preventive methods along with the development of strategies, analysing the past and future events.

The flood's risk is considered one of the most devastating risks with negative effects on the people's life, environment and local economy. The floods which occurred in the pre-development period are now more frequent and more destructive because of the climatic changes among with the land-use modifications.

The arrive of the Geographical Information System (GIS) and the introduction of computerized technology in water management are considered important steps in floods zones analyse along with flood management. The GIS platform provides simple methods of manipulation, analyse and interpretation of graphical and numerical information. In the last decades, the progresses made in the field of GIS made possible the integration of geomorphologic, hydrologic and weather variables within numerical models in order to forecast and to model the extreme events. Moreover, the advances made in the GIS platform, the development of remote sensing (the meteo satellites such as NEXRAD, Meteosat, GMS, TIR) along with the high-resolution digital elevation models make the floods modelling and forecast more accurate and more accessible.

The combination of GIS extensions with hydrological models have as result a considerable number of programs capable to model the water flow in rivers, streams and channels, such as: TUFLOW (flood and coastal simulation software), Flo-2D (Dimensional Flood Routing Software), WMS (Watershed Modelling System), WSS (Water System Software), MikeFlood (Flood Modelling Software), River-Cad, SMS (The Surface Water Modelling System) etc. . Each advance in the floods modelling brings new challenges related with the amount and quality of the information resulted along with the availability of the data needed.

In Romania, the flood modelling was undertaken from 2005 when Păcurar used mathematical models to calculate the maximum discharge of small brooks and to simulate the possible floods. In 2008, Bilaşco reviewed the methods and programs available for modelling the flash-floods. Earlier studies were initiated by Miţă (1992), Mustaţă (1973a, 1973b, 1974), Platagea (1958, $1965,1974)$ focusing more on mathematical models to calculate the maximum discharge of rivers or brook.

This study focuses on a small catchment area, located in the north-east part of Romania, within the Suceava plateau, at an average altitude of $350 \mathrm{~m}$. The Baranca brook was used as a pilot drainage basin for simulating the flash-floods and validating them with the 2010 flash-floods. The destruction capacity of such a small brook among with its size and shape rise many questions about the risk that it possesses.

The aim of this research is to provide: i) a practical and methodological study with information about the computerized programs Hec-Ras and HecGeo-Ras; ii) the utility of these programs in flood simulation; iii) the limitations of the computerized programs in flood analyses; iiii) the flashflood simulation accuracy.

\section{Study area}

The Baranca drainage basin, part of Siret basin, was chosen as a pilot catchment for verifying the utility of the programs Hec-Ras and respectively, HecGeo-Ras. The drainage basin of Baranca brook develops on the north-west slopes of Zvoristea Hills and partially on the north-east slopes of Dragomirna Plateau (Figure 1a). The geological substrate of the basin (Figure 2) evolved on 
Moldavian Platform where the geological deposits have a small inclination on NV-SE direction with values of 4,5-6 $\mathrm{m} / \mathrm{km}$ belonging to Volhinian period (where the detrital deposits are represented by alternations of sand and clay, plus layers of limestone and sandstone lenses and pebbles with thin intercalations of bentonites) (Băcăuanu 1980). The soils of the drainage basin encompass brown and grey podzols, sandy soils, levigated chernozems and meadow black soils (Băcăuanu 1980).

The brook originates from the south-west part of Pietriş Hill, in Zvoriştea village, at an altitude of $388 \mathrm{~m}$. The Baranca brook is affluent of Siret River, having a SV-NE flow direction, enclosed in the eastern group of rivers, the eastern type (outside Carpathian arch) and Suceava subtype. The brook collects its waters, mainly from Baranca forest and has as tributaries the brooks: A5, A4, Putreda and Prisosul (Figure 1b).

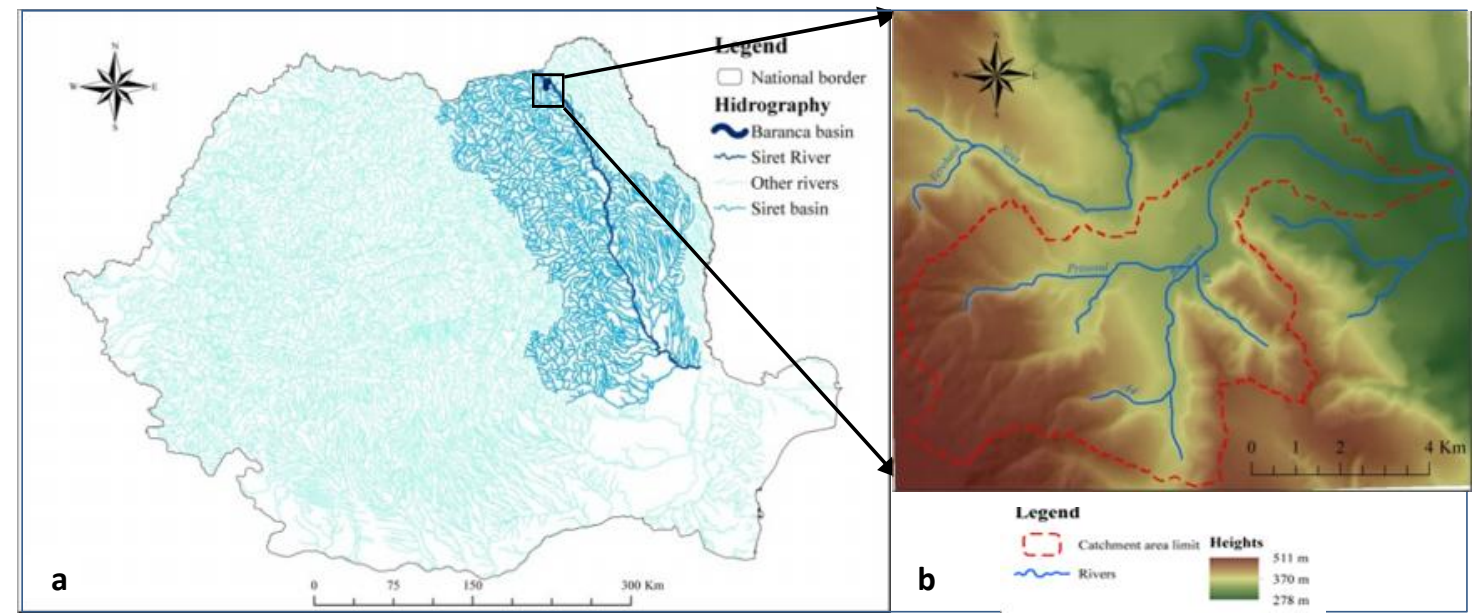

Figure 1a. Position of Baranca basin; 1b. The drainage basin of Baranca Brook. This figure is available in colour online at www.georeview.ro.

The climate of the Baranca drainage basin is part of the temperate continental climate with moderate influences typically for the areas located outside the Carpathian arch, in the climatic range of medium to low hills and plateaus (Sandu et al., 2008). This climatic type belongs to the Dragomirna Plateau zone, Fălticeni and Siret corridor sub-zone, being characterized by moderate temperatures with hot summers and cold winters as well as moderate precipitation regime (Nistor, 2009). The dynamics of the air masses is in relation with the Siret River valley. At the nearest station, Suceava, the mean annual temperature reaches $7.8^{\circ} \mathrm{C}$, the mean precipitation quantity is $602.9 \mathrm{~mm} /$ year (Nistor, 2009). In this area, the wind regime is influenced by the intensity of barometric centres, relief, altitude and orientation of the Siret River corridor so that the dominant winds are from the NW and SE while the annual average wind speed is about 3.9 $\mathrm{m} / \mathrm{s}$ (Nistor, 2009).

The drainage basin covers a surface area of $25.81 \mathrm{~km}^{2}$ and before reaching the Siret River, the brook covers $8.79 \mathrm{~km}^{2}$ and drains a considerable part of Zamostea village.

From a hydrologic point of view, the Baranca brook is part of the hydric oriental regime, characterized by high waters in spring-summer period and low waters in autumn-winter (Băcăuanu 1980). The hydrologic zone of the brook is specific for the hills and high plateaus unit, the subunit of structural plateaus of Dragomirna (Băcăuanu, 1980).

According with Strahler stream order, the Baranca basin encompasses brooks of 1, 2 and 3 order (Figure 3) which have low discharges, $2-5 \mathrm{~m} 3 / \mathrm{s}$, in normal climatic condition. 


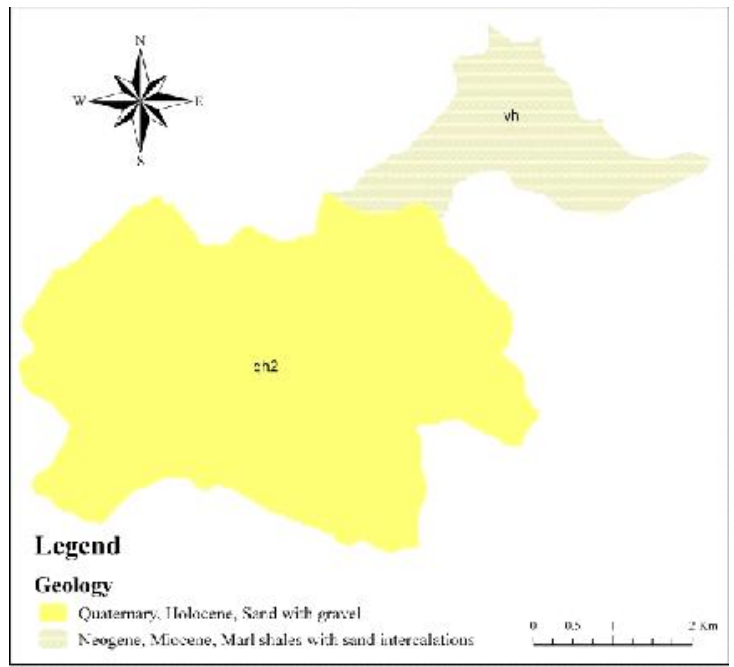

Figure 2. Baranca catchment geology. This figure is available in colour online at www.georeview.ro.

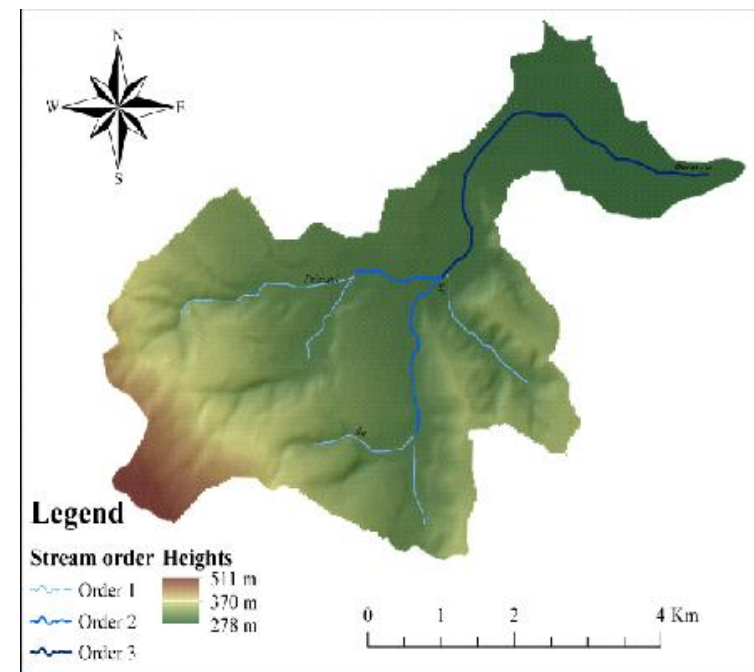

Figure 3. Stream classification by Strahler order. This figure is available in colour online at www.georeview.ro.

\section{Methodology}

In this study the programs Hec-Ras and HecGeo-Ras were used in order to simulate the behavior of the environment at the pressure of the flash-floods in a small drainage basin. It has to be mentioned the fact that the first problem addressed for this modeling programs was the accuracy in conditions of few variables known. The results were validated using the measurements undertaken immediately after the flash-floods of 2010 as well as the data provided by the Siret hydrometric station.

Hec-Ras is an informational program, an integrated system of software capable to simulate the water flow in brooks, rivers and anthropic channels using a numerical model. The program is onedimensional which means that there is no direct modeling of the hydraulic effects of the 
transversal profiles such as crooks, section forms and other aspects with bi- and tri-dimensional fluxes (Hec-Ras, 2010a). The geo-informational program, Hec-Ras, was developed by the research group of Hydrologic Engineering Centre, part of the Institute for Water Resources, U.S. Army Corps of Engineers (Hec-Ras, 2010a). Even though, from 1965 onwards the research institute developed many programs for river modeling, the first version of the Hec-Ras was released in 1995 in order to help managing the river, brooks and anthropic channels (Hec-Ras, 2010a). The HEC-GeoRAS program is an extension of the Hec-Ras developed by the cooperation between Hydrologic Research Engineering Center - HEC and Environmental Systems Research Institute ESRI, helping with the pre- and post- processing of the geometric date created in Hec-Ras (HecRas, 2010d).

The steady flow water surface profile is the most important component of Hec-Ras for calculating the water surface profiles of a flash-flood event from the plain and plateau zone when the flow is not modified over time. Moreover, the water surface profiles calculation is based on the onedimensional energy equation (Knighton 1998):

$$
Z_{2}+Y_{2}+\frac{a_{2} V_{2}^{2}}{2 G}=Z_{1}+Y_{1}+\frac{a_{1 V_{2}^{1}}}{2 g}
$$

where:

$Z_{1}, Z_{2}=$ elevation of the main channel inverts;

$\mathrm{Y}_{1}, \mathrm{Y}_{2}=$ depth of water at cross sections;

$\mathrm{V}_{1}, \mathrm{~V}_{2}=$ average velocities (total discharge/total flow area);

$a_{1}, a_{2}=$ velocity weighting coefficients;

$\mathrm{g}=$ gravitational acceleration;

$\mathrm{h}_{\mathrm{e}}=$ energy head loss.

The energy loses are evaluated through friction (using Manning equation, an empirical equation for gravitational flow) and expansion/compression (coefficient modified by the velocity) (HecRas, 2010a).

Hec-Ras uses the geometric representations DEM's (digital elevation model) and TIN's (triangular irregular networks) making the rivers modeling easier and less expensive. Thereby, the combination of GIS extension with Hec-Ras represents the base for flood simulation and indeed, for water flow in rivers. Moreover, the program Hec-GeoRas is an extension of the basic program Hec-Ras and contains a suite of procedures, instruments and utilities for processing the geospatial information in ArcGis (Hec-Ras,2010d).

\section{Flash-flood simulation}

The flash-flood simulation for the Baranca drainage basin can be structured in three important steps including: the DEM preparation in ArcGis, the pre-procession or the data creation in HecGeoRas, the procession of information in Hec-Ras and the flood simulation.

The digital elevation model used in this application was downloaded for free from ERSDAC: http://www.gdem.aster.ersdac.or.jp/. The data was generated from the information collected by the optical satellite - ASTER (Advanced Spaceborne Thermal Emission and Reflection Radiometer). ASTER GDEM or ASTER Global Digital Elevation Model is a product resulted from the partnership of Ministry of Economy, Trade and Industry - METI, Japonia and United States 
National Aeronautics and Space Administration - NASA, USA (METI and NASA (Ministry of Economy 2011). Until now, ASTER GDEM is the unique DEM which covers the entire world at a high resolution, 30m (METI and NASA (Ministry of Economy 2011)(Figure 4).

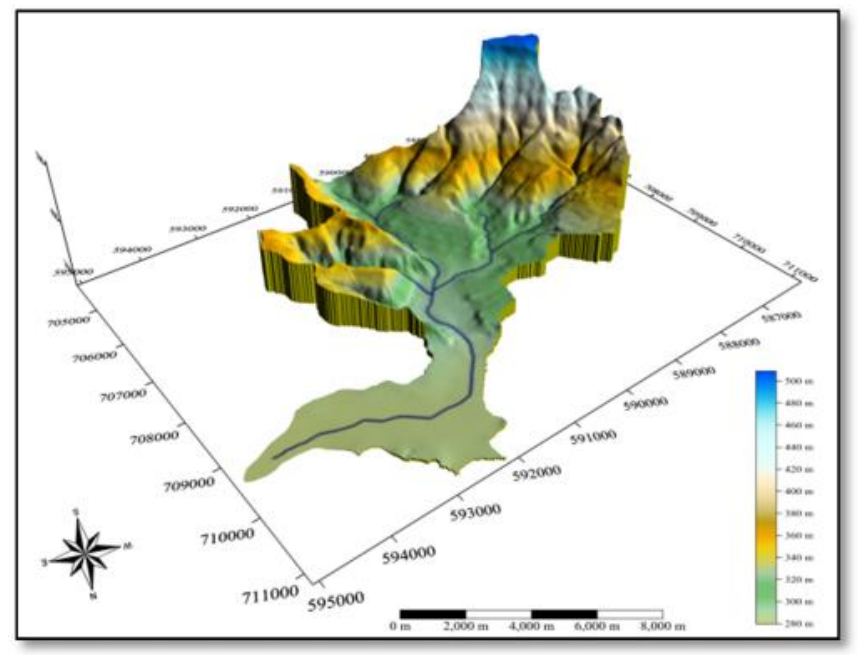

Figure 4. The Baranca catchment area, 3D Surfer model. This figure is available in colour online at www.georeview.ro.

In the application the drainage network was extracted automatically using the DEM, because digitizing it manually from the $25 \mathrm{k}$ maps would have generated important errors. The accuracy of the network is even higher because of the high resolution of the DEM, $30 \mathrm{~m}$, along with its capability to generate the temporary brooks.

The second step was the creation of RAS layers which were used for geometric data development. The data were automatically saved in a geo-database and represented the base for the hydraulic analyse in Hec-Ras. The principal layers used are presented in the following sections.

The Stream Centreline layer was used for digitizing the Baranca brook and its tributaries using lines; for each vector a name was given and the digitization was done from upstream to downstream.

The Cross Section Cuts Lines/ XS Cut Lines were used to create the transversal profile, perpendicular on the flow direction which covered the entire floodplain. Although the profiles can be manually created, in this study they were generated automatically with a distance in between of $25 \mathrm{~m}$ and afterwards corrected carefully. Initially, the profiles had only $X Y$ and coordinates while the $Z$ coordinate was automatically extracted from the DEM, the profile becoming 3D.

The Main Channel Banks helped to demark the floodplain using lines which intersect the transversal profiles and can be used not only on Hec-Ras but also in Hec-GeoRas.

The Flow Path Centreline is used to create different types of lines which will indicate the extension of the river water.

The Land Use layer is based on polygons which will assess the coefficient of roughness for each profile. The information for land-use was downloaded from the Corine Land Cover 2000 data set: http://earth.unibuc.ro/download/datele-corine-landcover-reproiectate-in-stereo70. What is more, each land-use polygon corresponds with a land-use category and has a $\mathrm{N}$-value, known as 
the Manning value or the roughness value which depends on the surface roughness, vegetation, channel irregularities and dimension, etc. . The Figure 5 depicts the categories of land-use in the Baranca drainage basin where a considerable part is covered by forest (the highest Manning values) which acts as obstruction in the floods way and enhances the flood speed while the surface covered by agricultural land (the lowest Manning values) allows the water extension.

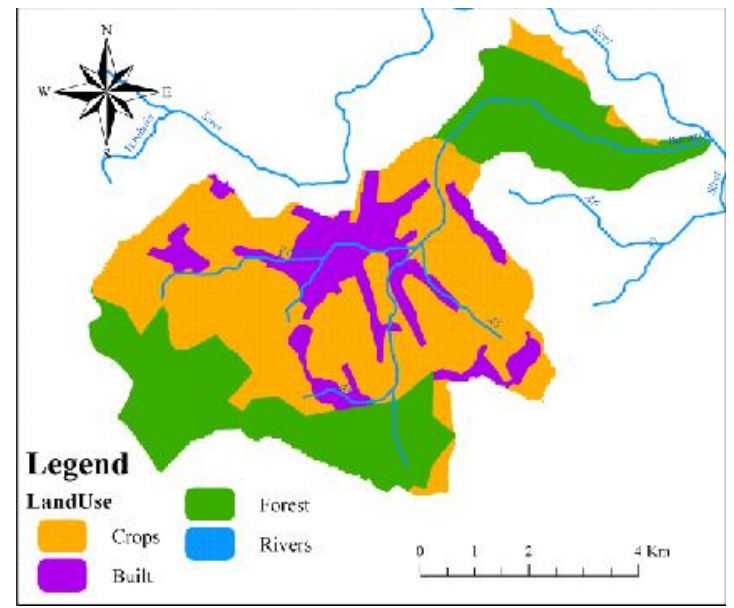

Figure 5. Land use in Baranca catchment. This figure is available in colour online atwww.georeview.ro.

In this study, the menu "the steady flow" was used as it indicates the water flow in block, without time-modification of the discharge value, characteristic for the flash-floods of small brooks. For the flow type it was selected the "subcritical flow" as it is characteristic for a small brook with low discharge values.

The information created in Hec-GeoRas was imported in Hec-Ras where the graphics, table and other instruments helped to verify, correct and modify the data.

In the Baranca basin the discharge values are not directly measured but knowing a couple a variables the specialists have reconstructed the flash-floods discharge for the main tributaries of 2010 floods of Siret River (SHI Siret, 2010a). The Baranca flash-flood discharge reached $70 \mathrm{~m}^{3} / \mathrm{s}$ (SHI Siret, 2010a).

The discharge values for the Baranca affluents where appreciated according to each tributary length, drainage basin, number of affluents etc.. The Hec-Ras program divided the Baranca brook in 9 sections, each section having the following flood's discharge:

- Baranca - A4, $1.1 \mathrm{~km}$ length, coincides with Baranca brook section from the origins until reaching A4 tributary with a discharge of $10 \mathrm{~m}^{3} / \mathrm{s}$;

- A4 - Baranca, $1.4 \mathrm{~km}$ length, coincides with A4 brook from its origins until meeting the Brook Baranca with a discharge of $10 \mathrm{~m}^{3} / \mathrm{s}$;

- Baranca - Prisosul, $2.2 \mathrm{~km}$ length, coincides with the section from Baranca brook until reaching the brook A4 at its confluence with Prisosul brook and has a discharge value of $20 \mathrm{~m}^{3} / \mathrm{s}$;

- Prisosul - Pârâul Putred, $2.6 \mathrm{~km}$ length, the Prisosul brook section from its origins until reaching the Putreda brook with a discharge of $20 \mathrm{~m}^{3} / \mathrm{s}$;

- Pârâul Putred - Prisosul, $1.1 \mathrm{~km}$ length, coincides with the Putreda brook from its origins until reaching the Prisosul brook, $20 \mathrm{~m}^{3} / \mathrm{s}$;

- Prisosul - Baranca, $1.4 \mathrm{~km}$ length, the Prisosul section from its confluence with Putreda brook until reaching Baranca, $40 \mathrm{~m}^{3} / \mathrm{s}$; 
- A5 - Baranca, $1.8 \mathrm{~km}$ length, A5 brook section, $10 \mathrm{~m}^{3} / \mathrm{s}$;

- Baranca - A5, $0.1 \mathrm{~km}$ length, Baranca section from its confluence with Prisosul until its confluence with $\mathrm{A} 5$ brook, $10 \mathrm{~m}^{3} / \mathrm{s}$;

- Baranca - Siret, $5.3 \mathrm{~km}$ length, corresponds with the final section of Baranca brook, from its confluence with Prisosul Prisosul until reaching the Siret River with a discharge value of $70 \mathrm{~m}$ $3 / \mathrm{s}$.

After introducing the discharge values, the Compute menu performs the flood simulation and calculates the flooded area and other parameters. The geometric model, 3D, is the base for the post-processing in Hec-GeoRas.

\section{Discussion}

The programs used in this application, Hec-Ras şi Hec-GeoRas, allows the simulation of the flood and the creation of the maps using pre-determined variables. The simulation is based on a DEM Digital Elevation Model with a $30 \mathrm{~m}$ resolution. As any other numerical model, the flood simulation has some limitation because of the digital elevation model resolution:

- on ortho-photos an overlay errors of $15 \mathrm{~m}$;

- the apparition of storage area which are low zone where the water accumulates, it emerges on the left side of the A5 tributary, near the confluence with Baranca brook and cannot be validated in the field because the discharge is usually under $1 \mathrm{~m}^{3} / \mathrm{s}$ and the storage areas appear at a discharge of more than $10 \mathrm{~m}^{3} / \mathrm{s}$;

- the apparition of blocked obstructions which are high zones which block the water flow; it emerges on the left side of the Baranca brook.

- the water extension depends on the digital elevation model resolution and precision; it corresponds with the reality but its correctness can be verified only by using direct measurement in the field.

Moreover, it would be necessary a digital elevation model at a higher resolution to be able to model more precisely the hydro-geometry of the river and the terrain topography. The flooded zone obtained by the programs could not be verified because of the unavailability of the satellite images during the flash-floods. It has to be mentioned the fact that the unique images available for Romania are the ones from ROSA (The Romanian Spatial Agency) for the principal rivers.

The results of the simulation undertaken were validated using the information collected from the field after the flash-floods that occurred in the summer of 2010 on Baranca brook.

The hydro-climatic regime for the superior Siret drainage basin, including the Baranca brook is characterised by a succession of dry periods with significant increases, in a short period of time, of the atmospheric precipitations and indeed of brooks discharge. Even though, in the Siret drainage basin the floods appear in the registers beginning with 1950, their frequency increased significantly over time. In this area the flash-floods represent an important risk factor among with a consequence of a given hydro-climatic regime.

In the superior basin of Siret river the most important floods recorded in the registers from Siret (located $16 \mathrm{~km}$ upstream Zamostea) station, were the floods that occurred in 1969, 2010, 2008 when the discharge reached between $847-1193 \mathrm{~m}^{3} / \mathrm{s}$ and the precipitation quantity exceeded $150 \mathrm{l} / \mathrm{m}^{2}$ (SHI Siret, 2010c). 
The flash-floods that occurred on 27-30.VI.2010 in the Siret basin and its brooks the discharge reached the historic levels, $1125 \mathrm{~m}^{3} / \mathrm{s}$ on $29.06,13^{30}$, at Siret hydrographic station (situated $16 \mathrm{~km}$ upstream Zamostea village). The reconstructed discharge on the Baranca brook indicate that the brook reached 70-75 m³ $/ \mathrm{s}$ on 29-30.06.2010 (Administraţia Bazinală de Apă Siret, 2010). The destructive effects of the flash-floods that occured in June 2010 show that the dicharge values registered were ten times higher than the normal values for that period.

The synoptic conditions from the superior basin of Siret River indicated an atmospheric instability between 21.06.2010 and 1.07.2010, which brought important precipitations (Sistemul Hidrotehnic Independent Siret 2010). It has to be mentioned that the high rainfalls which inducted the flash floods were a result of the air masses of the pontic cyclone, with east-west direction which met the east-European ones, enhancing the precipitation amount and their torrential character (Sistemul Hidrotehnic Independent Siret 2010). At Zvoriştea hydrometric station, in the interval of 21-28.06 the precipitation quantity was quite stable falling between 2$50 \mathrm{~mm} / 24 \mathrm{~h}$. On 29.06 the precipitation quantity culminated and reached $115.1 \mathrm{~mm} / 24 \mathrm{~h}$ followed, on 30.06 , by a smallest quantity, $9.9 \mathrm{~mm} / 24 \mathrm{~h}$. In the context of a saturated soil, even the smallest quantity of precipitation was important in maintaining the soil humidity, reducing the infiltrations and enhancing the drainage.

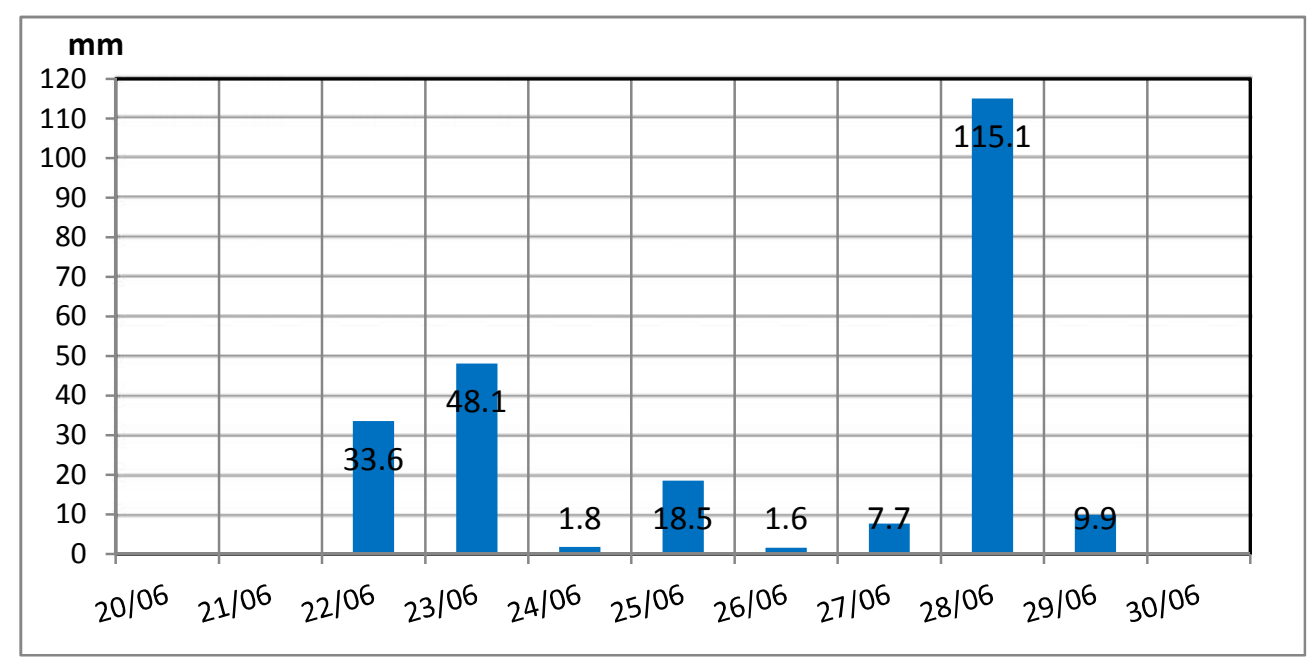

Figure 6. Precipitation quantity 20.06-30.06.2010, Zvoriştea hydrometric station (SHI Siret, 2010c). This figure is available in colour online at www.georeview.ro.

The flash floods that occurred on 29-30.06.2010 affected the central zone of Zamostea village along with the Nicani and Lunca villages damaging more the 120 houses. The causes of the 2010 events can be summarized at it follows:

- natural - heavy rainfalls, $115.1 \mathrm{~mm} / 24 \mathrm{~h}$, registered on 29.06 .2010 , at Siret hydrometric station; along with the factors of the basin: slope, altitude, aspect, soil, geology, vegetation;

- anthropic - excessive wood falling, village expansion on the floodplain, intensive land-use.

The village was affected by two flash-flood waves, one in the afternoon of 28.06 and the other one in the morning of 29.06. Even if, on the Baranca brook the discharge values are not undertaken, the measurement worked out immediately after the flash-floods reveals the fact that the flood wave reached almost $1.2-1.5 \mathrm{~m}$ in depth in the central zone of Zamostea(Figure $7 \mathrm{a}, \mathrm{b})$ and Nicani and almost $0.5-1 \mathrm{~m}$ in Lunca. The field papers filled after the floods show that the 
values of the roads and bridges destroyed reaches almost 2,600,000 lei, while the value of the destroyed houses was almost 6,000,000lei. The financial help for reconstructing the houses, rehabilitating the roads and bridges was given by the government and by the humanitarian organizations.

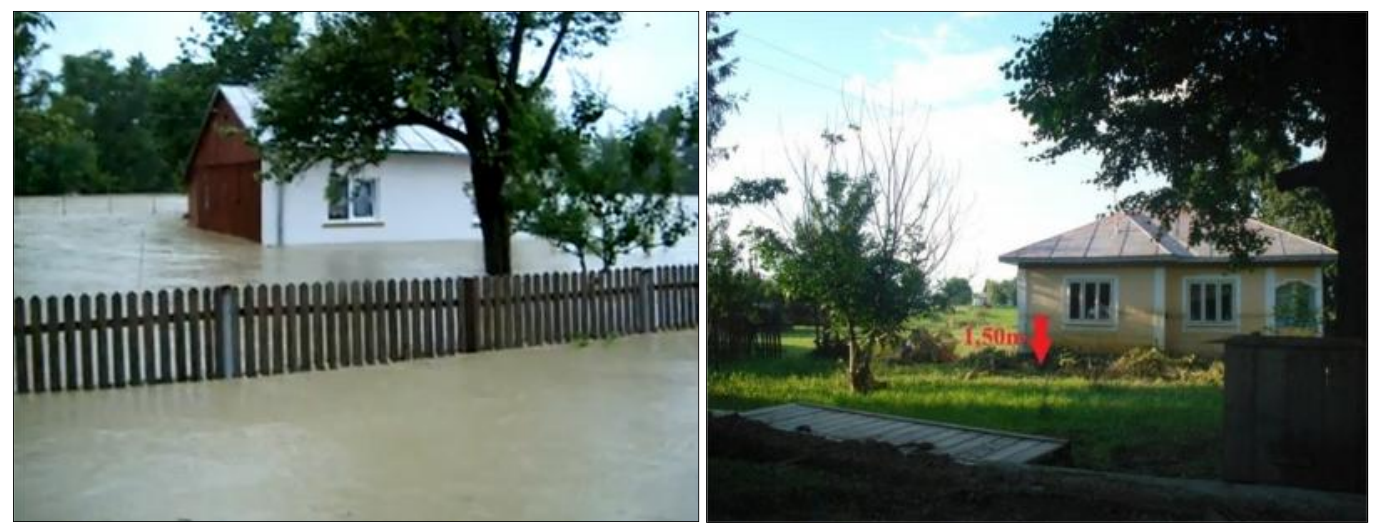

Figure 7a. House from south-west zone, Zamostea; 7b. House from central - west zone, Zamostea. This figure is available in colour online at www.georeview.ro.

In Baranca-Siret section, in the forest zone, Lunca-Nicani, and in the central zone of the village covered by agricultural field, situated at the base of Hărăgeni Hill, the water depth reaches between 2 and 3 metres (Figure 8). The high depth of the water along with the water extension is explained by the density of forest vegetation along with the Hărăgeni and Nicani hills which will act as barricades. The measurement undertaken in the field immediately after the inundation correspond with the information provided by the program.

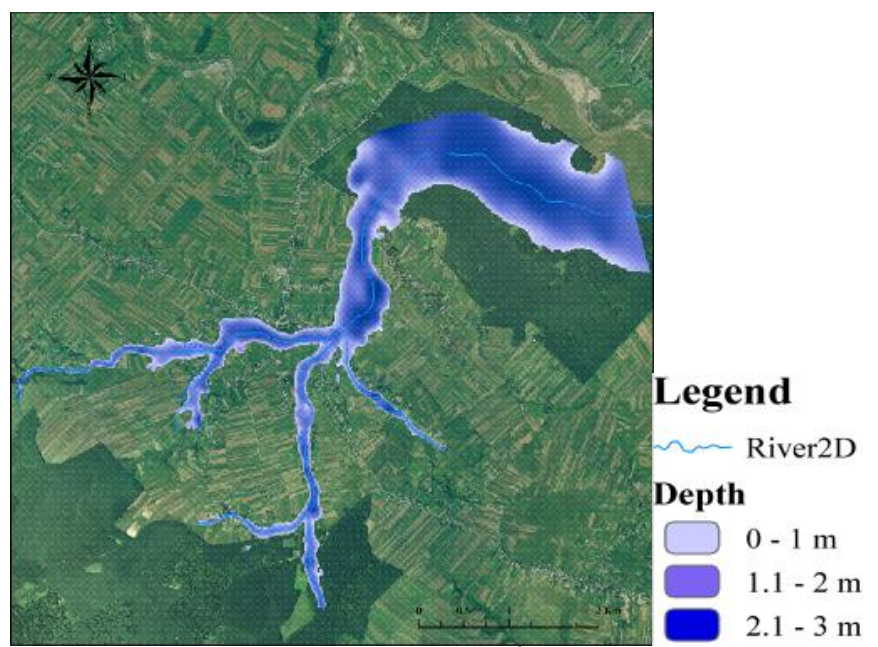

Figure 8. The flooded zone at a discharge value of $70 \mathrm{~m}^{3} / \mathrm{s}$. This figure is available in colour online at www.georeview.ro.

The Figure 9 shows that the water velocity increases in the same time with the depth so that in the narrow zones the total velocity is higher, ranging from 0.71 and $1.05 \mathrm{~m} / \mathrm{s}$, and decreases near the banks. In the last section, near the Siret River reach the velocity decreases because of the terrain morphology which allows the extension of the water. 


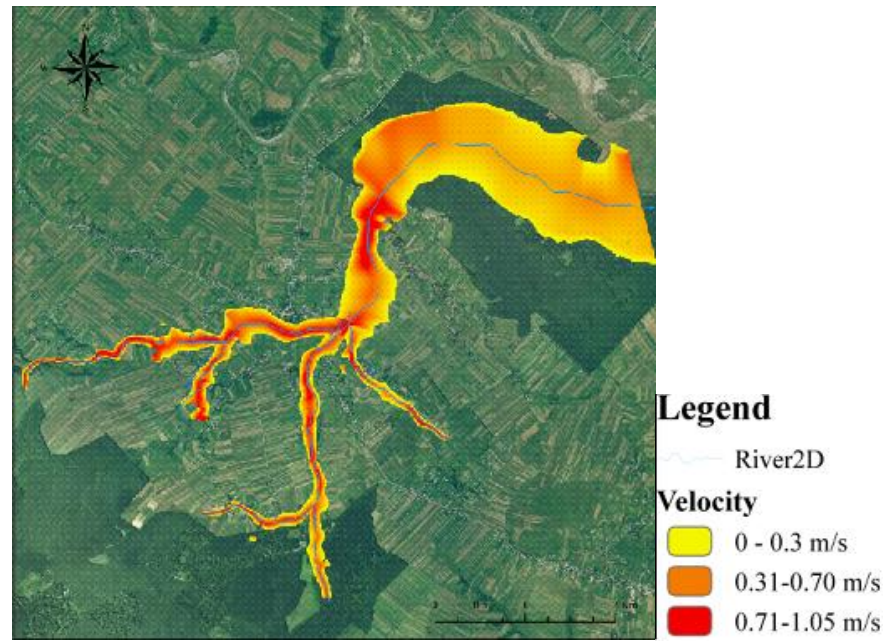

Figure 9. The water velocity. This figure is available in colour online at www.georeview.ro.

The water velocity, in transversal section varies in time and space because of the slope angle, water depth at a given point, roughness and configuration of the riverbed. Moreover, not only the depth but also the velocity of the water flow increases from the bank to the middle of the river channel or from one bank to another and it is caused by the turbulence flow, the friction coefficient between the brook water and its banks.

The Hec-Ras allows the work and export of the plots for the most important variables such as: flooded area - width and perimeter, water velocity, shear stress.

It has to be mention the fact that the values that appear on the graphic are automatically averaged. For the graphic representation of the flood variables it was chosen the most important section of the brook, the Baranca-Siret one, to avoid the overlays and the illegibility of the graphics.

The horizontal axis of the figures 10-12 indicate the main channel distance (Baranca-Siret section), where $0 \mathrm{~km}$ is the confluence point of Baranca with Siret while the $5 \mathrm{~km}$ represent the Baranca after receving all the affluents.

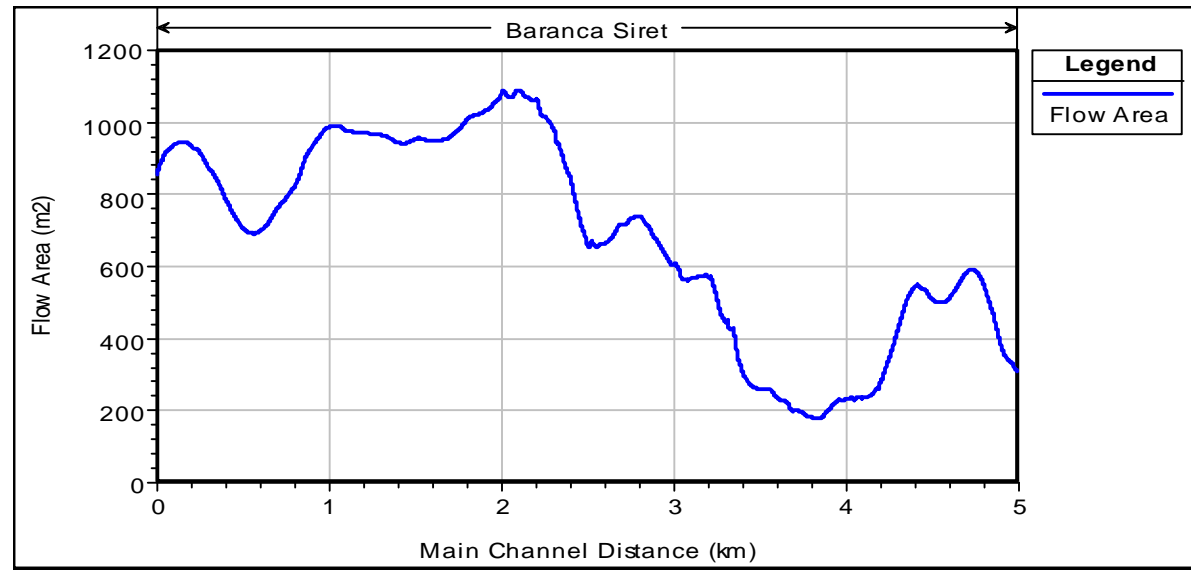

Figure 10. The distribution of flow area. This figure is available in colour online at www.georeview.ro. 


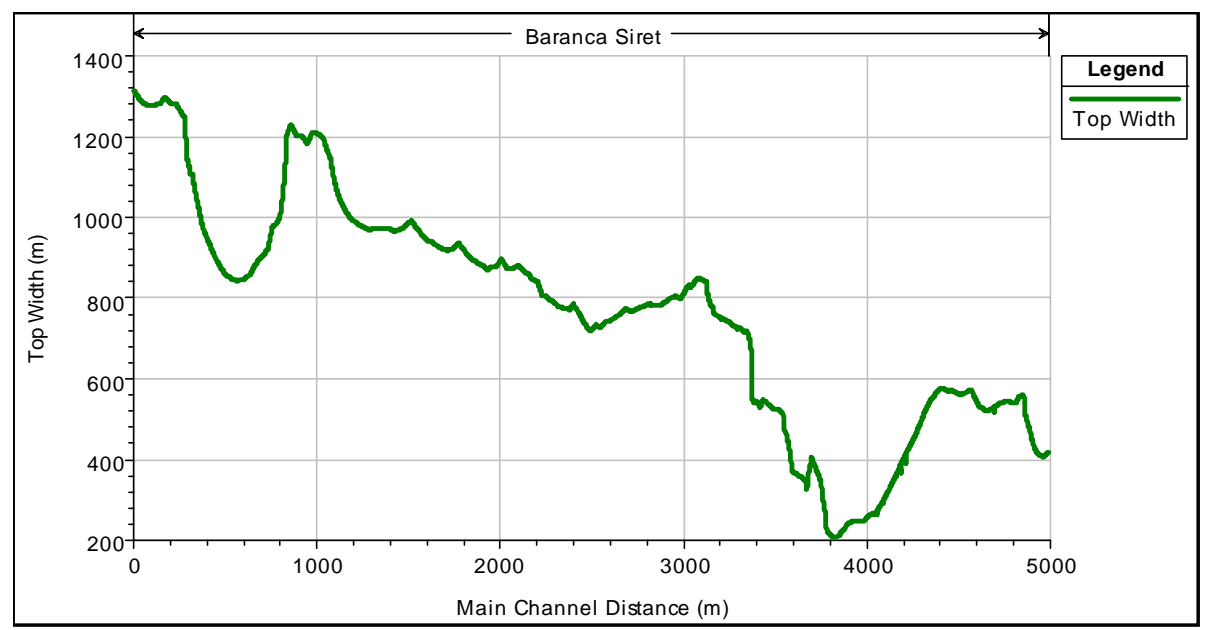

Figure 11. The distribution of top width. This figure is available in colour online at www.georeview.ro.

The wetted/flow area is represented by the river-bed area which is in direct contact with the water. In Figure 10 wetted area of the Baranca-Siret section is oscillating between $120 \mathrm{~m}^{2}(\mathrm{~km}$ 3.8) and $1080 \mathrm{~m}^{2}(\mathrm{~km} \mathrm{2.1)}$. Moreover, where the wetted area is decreased, the top width and water velocity is increasing. For example, at $3.8 \mathrm{~km}$ the wetted surface decrease from $600 \mathrm{~m}^{2}$ $(4.2 \mathrm{~km})$ to $200 \mathrm{~m}^{2}$ while the water velocity increases from $0.13 \mathrm{~m} / \mathrm{s}(\mathrm{km} 4.2)$ to $0.39 \mathrm{~m} / \mathrm{s}(\mathrm{km} 3.7)$.

The Figure 12, shows that the zone which precedes the forest area with the pozitive relief form represented by the hills Nicani and Hărăgeni, straitens the brooks valley determining the decrease of the wetted area and the increase of the water coloumn, velocity and discharge. For example, in the interval between $\mathrm{km} \mathrm{0-5}$ the flooded zone is getting straitened among with the intensification of the velocity values.

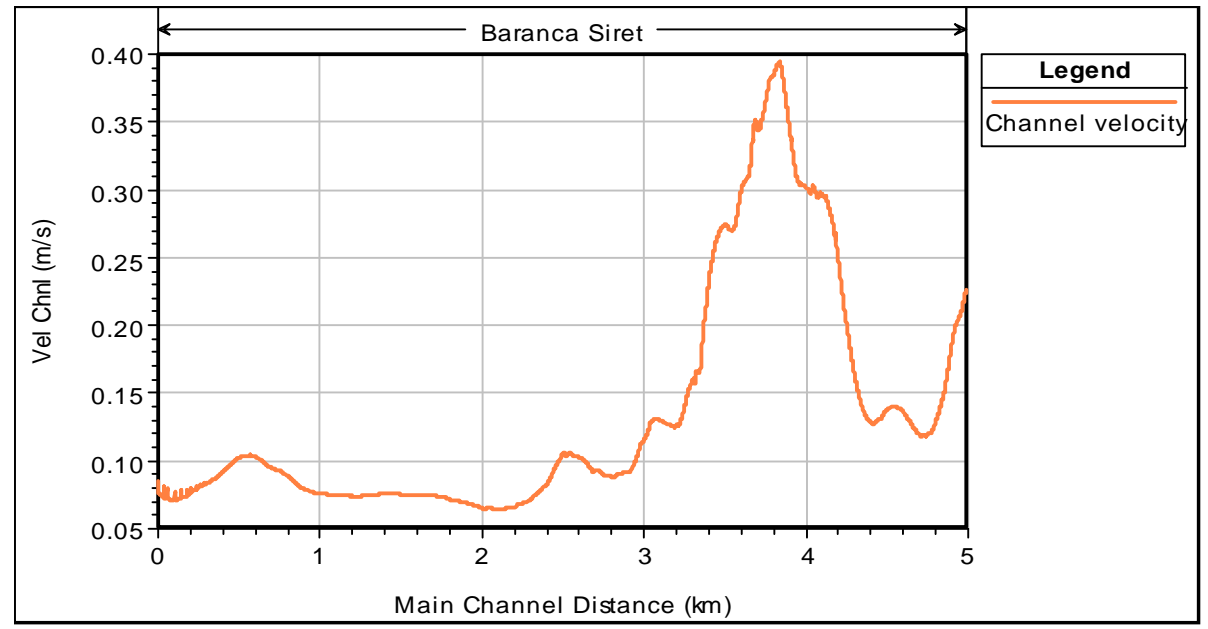

Figure 12. The distribution of total velocity. This figure is available in colour online at www.georeview.ro.

The forecast and the flood simulation are considered critical instrument in the program of civil protection. The flooded zones mapping is considered the base for the flood management because the identification of the risk zones will help in elaborating the management programs for preserving the flooded zones, preparing and avoiding the hazard. 
The floods that occurred in 2010 in Romania show that the majority of the villages are located in the action zone or floodplain of the rivers and their tributaries (Romanescu, 2009). The economic and material losses due to the floods demonstrate that the human-beings cannot control the nature but they have the power to manage and reduce the costs of cohabitation with it. A national and local program of the basin management will help in managing the hydrological phenomenon.

\section{Concluding remarks}

The simulation of the 2010 flash-floods that occurred in the Baranca drainage basin was used to provide a realistic picture of informational programs that can be used for floods optimal management. In this study two computerized programs were used, one-dimensional Hec-Ras and Hec-GeoRas which simulate the water flow in creeks, streams, rivers or anthropogenic canals using numerical models. The current investigation was limited by the data unavailability along with the limited access to the field measurements.

The programs used are free, easy to use for anyone with basic knowledge about this kind of software. This program may be integrated into any flood management strategy or in any watershed plan and may provide the necessary support for other potential flood risk areas. It has to be highlighted the fact that a simulation program such as Hec-Ras cannot include all the variables that are in the field. Moreover, like any other informational program Hec-Ras has limitations, but with an acceptable margin of error can be used in the analysis of possible floods.

Baranca drainage basin develops on the northwest slopes of Zvoristea hill and partly on the north-easterners slopes of the Dragomirna plateau at an altitudine of $388 \mathrm{~m}$. The Baranca brook has a surface area of $25.813 \mathrm{~km}^{2}$ and four main tributaries.

The flood simulation involved the use of a DEM, the creation of the data in HEC-GeoRAS, the data processing in HEC-RAS and flood simulation, the post-processing in HEC-GeoRAS and flood maps creation.

The discharge values used for the flash-flood simulation ranged from $10 \mathrm{~m}^{3} / \mathrm{s}$ to $70 \mathrm{~m}^{3} / \mathrm{s}$ depending on the size of each brook and field assessments due to the fact that the discharge of the small brooks are not directly measured. The discharge for Baranca brook were recosntructed by the authorities responsible with Siret River management.

During the flood, at a discharge of $70 \mathrm{~m}^{3} / \mathrm{s}$ (in the final section), water covered an area of 5.14 $\mathrm{km}^{2}$ while the water depth reached between $0.1 \mathrm{~m}$ to $3 \mathrm{~m}$, depending on terrain morphology. Compared with field measurements undertaken in residential areas immediately after the floods, the water depth coresponds with the reality. The most affected areas of Zamostea village were the center, the Nicani and Lunca villages where the damages reached approximately $9,000,000$ lei. The other variables analyzed in HEC-RAS such as shear stress could not be validated with field data.

Future research should therefore concentrate on the investigation of the flash-flood simulation on small brooks using higher resolution digital elevation models, an accurate data-base of brook variables which should include, mainly, the discharge record, a long record of precipitation quantity as well as complex field measurement before and after the flash-flood. Moreover, it would be necessary to reconsider and introduce the complex variables into the simulation such 
as: relief conditions - slope, energy, orientation; more detailed soil analyse; up-to-date land-use categories, etc.

Taking everything into consideration, the development of simulation programs, the flood mapping, the continuous meteorological and hydrological monitoring, the flash-flood effects would not be avoided but their effects will be mitigated.

\section{References}

Armaș I. 2008. Percepţia riscurilor naturale: cutremure, inundaţii, alunecări. București, Editura Universităţii din Bucureşti.

Băcăuanu V. 1980. Podişul Moldovei. București, Editura Ştiinţifică şi Enciclopedică.

Bilaşco Ş. 2008. Implementarea SIG în modelarea viiturilor de versant. București, Casa Cărţii de Ştiinţă.

Carpenter M. 2009. How to better understand and manage risk. USA, John Wiley and Sons.

Dao H., Peduzzi P. 2004. Global evaluation of human risk and vulnerability to natural disasters. Envirolnfo 1: 435-446.

Dingman S. L. 2009. Fluvial Hydraulics. Oxford, Oxford University Press.

Environmental Systems Resource Institute, E. 2010. ArcMap Redlands, California., ESRI. Golden Software. 2012. Surfer 11 Self-Paced, Training Guide. http://downloads.goldensoftware.com/guides/Surfer11TrainingGuide.pdf (Accessed 10.05.2012)

Grecu F. 2009. Hazarde si riscuri naturale. București, Editura Universitară.

Knighton A. D. 1998. Fluvial Forms and Processes: A New Perspective, Hodder Arnold.

Kollinger M., Vondráček K., Šeblová V., Zdražil J., Jirka J., Vokounová L. 2003. Flood simulation and visualization. Central European Seminar on Computer Graphics. Slovakia.

Leavesley G., Lins H., Nobilis F., Parker R., Schneider V., Van De Ven F. 1997. Destructive Water: Water-Caused Natural Disasters - their Abatement and Control. The International Association of Hydrological Sciences. The International Conference on Destructive Water:Water Caused Natural Disasters, their Abatement and Control.California: 239. http://itia.ntua.gr/hsi/redbooks/239/iahs 239 0000.pdf (Accesed 11.06.2012)

McCuen R. H. 1998. Hydrologic analysis and design, Prentice Hall.

METI, NASA 2011. Aster Global Digital Elevation Model (GDEM). http://www.jspacesystems.or.jp/ersdac/GDEM/E/ (Accessed 1.07.2012).

Miţă P. 1992. Cercetări pentru determinarea principalelor elemente caracteristice al scurgerii de apă şi aluviuni în bazine reprezentative. București, I.M.H.

Mustaţă L. 1973a. Calculul debitelor maxime din ploi pe râurile din România. Studii de hidrologie 36.

Mustaţă L. 1973b. Probleme privind calculul debitelor maxime pe râurile mici. Studii de hidrologie 36. 
Mustaţă L. 1974. Contribution aux problemes de la determiniation des debits maxima engendres par les pluies sur des petite rivers. Meteorology and Hydrology 4(2).

Musy A. 2010. Hydrology: A Science of Nature. London, Science Publishers.

Mutihac V., Ionesi I. 1974. Geologia României. București, Editura Tehnică.

Nistor B. 2009. Podişul Sucevei - Studiu termo-pluviometric (rezumat). Ph.D. Thesis, Universitatea Alexandru Ioan Cuza laşi.

O'Riordan T. 2000. Environmental science for environmental management, Prentice Hall.

Păcurar V. D. 2005. Cercetări privind scurgerea şi eroziunea în bazine hidrografice montane prin modelare matematică şi simulare. Ph.D. Thesis, Universitatea Transilvania Braşov.

Platagea G., Platagea M. 1958. Distribuţia teritorială şi calculul debitelor maxime pluviale pe râurile din România. Meteorologia, hidrologia şi gospodărirea apelor 3.

Platagea, G., Platagea, M. 1965. Calculul debitelor maxime pluviale pe râurile din România în cazul când lipsesc datele din observaţii directe. Studii de hidrologie 12: 3-32.

Platagea M. 1974. Caracteristicile de calcul ale ploilor torenţiale necesare în determinarea debitelor maxime pe versanţi şi în bazinele hidrografice mici de pe teritoriul României. Revista Hidrotehnica. București.

Popa A. 1996. Morfometria meandrelor râului Siret pe teritoriul României. Lucrările seminarului geografic Dimitrie Cantemir (15-16).

Rădoane M., Rădoane N. 2003. Impactul construcţiilor hidrotehnice asupra dinamicii reliefului. Riscuri şi catastrofe: 174-185.

Rădoane M., Rădoane N. 2004. Lacurile de baraj din bazinul râului Siret. Analele Universităţii Ştefan cel Mare Suceava: 77-88.

Romanescu G. 2009. Evaluarea riscurilor hidrologice. Iași, Editura Terra Nostra.

Sandu I., Poiană I., Pescaru V.I. 2008. Clima României, Editura Academiei Române. Sanders B. F. 2007. Evaluation of on-line DEMs for flood inundation modeling. Advances in Water Resources 30(8): 1831-1843.

Schumm S. A. 2005. River Variability And Complexity, Cambridge University Press.

Shaw E. 1994. Hydrology in Practice, Taylor \& Francis.

Sistemul Hidrotehnic Independent Siret. 2010a. Rapoarte definitive privind inundaţiile din anul 2010. Technical report, Siret.

Sistemul Hidrotehnic Independent Siret. 2010b. Raport anual de sinteză privind activitatea de urmărire a comportării construcţiilor desfăşurată la A.B.A Siret în anul 2010. Technical report, Siret.

Sistemul Hidrotehnic Independent Siret. 2010c. Raport privind fenomenele hidrometeorologice de risc din perioada 17.06-10.07 2010 din spaţiu hidrografic Siret. Technical report, Siret.

Stângă I. 2007. Riscurile naturale. Noţiuni şi concepte. Iași, Editura Universităţii Al.I.Cuza.

US Army Corps of Engineers, Hydrologyc Engineering Center. 2010a. HEC-RAS River Analysis System. User's Manual. USA. http://www.hec.usace.army.mil/software/hecras Ldocumentation/HEC-RAS 4.1 Users Manual.pdf (Accessed 11.06.2012). 
US Army Corps of Engineers, Hydrologyc Engineering Center. 2010b. HEC-RAS River Analysis System. Hydraulic Reference Manual. USA. http://www.hec.usace.army.mil /software/hecras/documentation/HEC-RAS 4.1 Reference Manual.pdf (Accessed 1.05.2012)/

US Army Corps of Engineers, Hydrologyc Engineering Center. 2010c. HEC-RAS River Analysis System. Application Guide. USA. http://www.hec.usace.army.mil/software/hecras ddocumentation/HEC-RAS 4.1 Applications Guide.pdf (Accessed 15.06.2012).

US Army Corps of Engineers, Hydrologyc Engineering Center. 2010d. HEC-GeoRAS/GIS Tools for Support of HEC-RAS using ArcGIS. User's Manual. USA. http://www.hec.usace.army.mil/software/hecgeoras/documentation/HECGeoRAS42 Us ersManual.pdf (Accessed 29.05.2012).

Varley A. 1994. Disasters, development and environment, John Wiley\&Sons.

Ward R. C. 1978. Floods: a geographical perspective, Wiley.

White G. 1974. Natural hazards: local, national, global. New York, Oxford University Press.

Wisner B., Blaikie P., Cannon T., Davis I. 2003. At Risk: Natural Hazards, People's Vulnerability and Disasters. London, Routledge. 